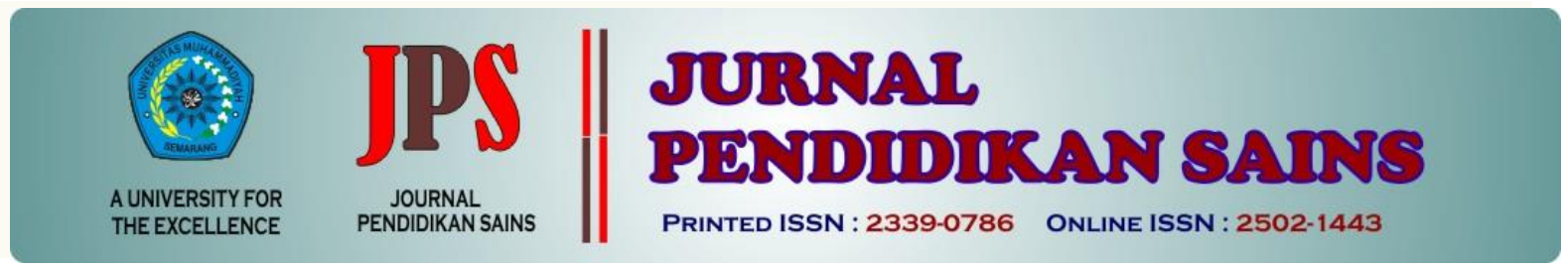

http://jurnal.unimus.ac.id/index.php/JPKIMIA

\title{
STUDI KASUS MANAJEMEN SISTEM PEMBELAJARAN GOOGLE CLASSROOM PADA PERKULIAHAN ALAT UKUR FISIKA
}

\author{
Oleh: \\ Melkyanus Bili Umbu Kaleka ${ }^{1}$, Yasinta Embu Ika ${ }^{2}$, Maria Elfrida Deno ${ }^{3}$ \\ ${ }^{123}$ Prodi Pendidikan Fisika, FKIP Universitas Flores, Indonesia
}

\begin{tabular}{ll}
\hline \multicolumn{2}{l}{ Article history } \\
\hline Submission & $: 2020-07-24$ \\
Revised $\quad: 2020-09-18$ \\
Accepted & $: 2020-09-23$
\end{tabular}

Keyword:

Keywords: Google Classroom, online learning, learning management system, learning activities, learning achievement

\begin{abstract}
This study aims to describe student learning activities during the covid pandemic 19 using the google classroom learning management system and student learning achievement in physics measuring devices. This research is an ex post facto research. The participants in this study were all semester II students of the Physics Education Study Program, while the object of the research was learning activities, learning achievement, and online learning using the google classroom learning management system. Data collection techniques using questionnaires and documentation. Data analysis techniques using qualitative and quantitative descriptive analysis. The results showed that student learning activities used the google classroom learning management system for 6 indicators, namely; a) online lectures are good criteria, b) download literature is in good criteria, c) reading the literature including the criteria is good enough, d) behave based on one's own initiative, including good criteria, e) responsibility and discipline criteria are good, and f) independent attitude is criteria as good enough. Student learning achievement based on an average score of 78 with good criteria.
\end{abstract}

\section{Pendahuluan}

Dampak Virus Corona atau Covid-19 telah dirasakan oleh dunia pendidikan. UNESCO menyebutkan bahwa kurang lebih 69 negara di dunia telah menutup sekolah dan menerapkan pembatasan pembelajaran sekolah maupun Universitas. Presiden Republik Indonesia Ir. $\mathrm{Hj}$. Joko Widodo sudah menghimbau untuk bekerja, belajar, dan beribadah dari rumah semasa pendemi virus corona. Pemerintah juga telah membatalkan Ujian Nasional (UN) 2020. Beberapa Perguruan

*Corresponding Author:

$\begin{array}{ll}\text { Nama } & \text { : Melkyanus Bili Umbu Kaleka } \\ \text { Lembaga } & : \text { FKIP Universitas Flores } \\ \text { Email } & : \text { melkycitra15@gmail.com }\end{array}$

Tinggi Negeri maupun Swasta telah mengambil kebijakan kegiatan pembelajaran dengan memanfaatkan sistem manajemen pembelajaran online seperti, google classroom, zoom dan sebagainya. Universitas Flores (UNIFLOR), merupakan salah satu Perguruan Tinggi Swasta yang ada di Provinsi NTT telah memiliki sistem akademik berbasis daring (online) yang dapat diakses melalui http://e-learning.uniflor.ac.id/. Melalui laman tersebut UNIFLOR telah siap melaksanakan sistem manajemen pembelajaran akademik berbasis online atau kuliah online. 
Suasana akademik yang terjadi di Universitas Flores khususnya pada Program Studi Pendidikan Fisika yang terjadi sebelum mewabahnya virus corona, sistem perkuliahan masih bersifat konvensional. Sistem pembelajaran tatap muka antara mahasiswa dan dosen sebanyak maksimal 16x pertemuan wajib dilakukan. Perubahan seluruhnya menjadi berbasis online dalam proses pembelajaran tentunya akan berdampak terhadap aktivitas dan capaian hasil belajar yang terdapat dalam silabus ataupun Rencana Pembelajaran Semester. Penguasaan Teknologi yang masih terbatas dalam mempelajari aplikasi-aplikasi yang telah tersedia seperti google classroom, zoom, admode, dan lain-lain, tingkat ekonomi mahasiswa yang rendah karena membutuhkan biaya untuk mengisi data, serta adanya kecenderungan akan rendahnya motivasi mahasiswa untuk mencari informasi-informasi perkuliahan secara online, tentunya akan berpengaruh terhadap aktivitas dan hasil belajar mahasiswa. Adanya permasalahan ini, tentunya menjadi tantangan bagi dosen dan mahasiswa dalam melaksanakan proses pembelajaran secara online. Berdasarkan hal tersebut perlu dilakukan penelitian untuk mendeskripsikan aktivitas perkuliah yang dilakukan secara online menggunakan Sistem Manajemen Pembelajaran google classroom.

Tujuan yang ingin dicapai dari penelitian ini adalah untuk mendeskripsikan aktivitas pembelajaran online menggunakan sistem manajemen pembelajaran google classroom pada mata kuliah Alat Ukur Fisika mahasiswa semester 2 program studi pendidikan fisika. Berdasarkan penelitian terdahulu menunjukkan terdapat pengaruh yang signifikan aktivitas belajar mahasiswa setelah menerapkan sistem pembelajaran google classroom (Nirfayanti \& Nurbaeti, 2019). Sejalan dengan penelitian yang dilakukan Waryanto (2006), bahwa keuntungan dari model pembelajaran online adalah dapat digunakan untuk menyampaikan pembelajaran tanpa dibatasi ruang dan waktu, dapat menggunakan berbagai sumber yang sudah tersedia di internet, bahan ajar relatif mudah untuk diperbaharui. Selain itu lebih meningkatkan kemandirian mahasiswa dalam melakukan proses pembelajaran. Hasil penelitian yang dilakukan Susilawati, juga menunjukkan bahwa media pembelajaran online yaitu facebook dapat dijadikan media pembelajaran yang dapat meningkatkan hasil belajar siswa (Susilawati \& Sari, 2019).
Google Classroom adalah aplikasi yang memungkinkan terciptanya ruang kelas virtual. Media pembelajaran ini dapat dimanfaatkan untuk membantu meningkatkan hasil belajar mahasiswa (Gheytasi et al., 2015). Sistem manajemen pembelajaran ini bisa menjadi sarana distribusi tugas, submit tugas bahkan menilai tugas-tugas yang dikumpulkan. Selain itu, sistem ini dapat membantu dosen dan mahasiswa dalam melaksanakan proses belajar. Melalui sistem tersebut baik mahasiswa maupun dosen dapat mengumpulkan tugas, menyalurkan tugas, menilai tugas dimanapun tanpa terikat ruang dan waktu (Pradana, 2017).

Sistem manajemen pembelajaran Google classroom dibuat untuk mempermudah interaksi dosen dan mahasiswa dalam dunia maya. Aplikasi ini memberi ruang bagi dosen untuk memperluas segala ide, gagasan, serta keilmuan yang dimilikinya kepada mahasiswa. Terdapat fleksibiltas waktu dalam membagikan kajian keilmuan dan juga memberi tugas mandiri bagi mahasiswa. Sistem manajemen juga membuka ruang diskusi antara mahasiswa dan dosen. Selain berdampak positif, salah satu kelemahan dalam mengaplikasikan google classroom yaitu membutuhkan akses internet yang memadai (Izenstark \& Leahy, 2015). Sistem manajemen pembelajaran google classroom digunakan oleh siapa saja yang tergabung dengan kelas virtual, yang telah didesain oleh Dosen seperti kelas sesungguhnya.

Pembelajaran dapat terjadi dengan baik jika ada aktivitas belajar (Sardiman, 2007). Aktivitas belajar dapat diartikan kegiatan emosional yang ditunjukkan untuk mencari informasi baik secara mandiri atau kelompok, secara langsung ataupun tidak langsung yang terproses sehingga ada perubahan sikap, nilai dan pengetahuan (Nurdin, 2013). Aktivitas belajar juga dapat diartikan sebagai proses belajar dalam selang waktu tertentu untuk menyelesaikan berbagai permasalahan (Suyanto \& Jihad, 2013).

Sesuai definisi di atas maka dapat disimpulkan bahwa aktivitas belajar mahasiswa adalah suatu usaha yang dilakukan mahasiswa secara mandiri atau kelompok yang melibatkan pemikiran atau kegiatan emosional yang dapat mengarah pada perubahan sikap, nilai dan pengetahuan yang lebih baik. Aktivitas belajar yang baik berdampak pada prestasi belajar yang baik pula. Prestasi belajar dapat diartikan kemampuan yang diperoleh setelah seorang 
pelajar atau mahasiswa menyelesaikan berbagai aktivitas berkaitan dengan keilmuan yang dipelajari (Nuriyah, 2014). Menurut Sudjana, (2009), prestasi belajar adalah hasil yang dicapai oleh siswa dengan kriteria-kriteria tertentu. Pendapat lain juga menyebutkan bahwa prestasi belajar adalah kemampuan menyelesaikan berbagai tugas belajar yang ditempuh dalam waktu tertentu (Ananda \& Rafida, 2017).

Capaian pembelajaran mahasiswa terukur dari prestasi belajar yang diperoleh, berdasarkan pelaksanaan evaluasi yang dilakukan. Perhitungan hasil evaluasi belajar tertuang pada buku Peraturan Akademik Universitas Flores (2019):

a) Mengukur kemampuan akademik mahasiswa dengan mempertimbangkan pengetahuan, sikap dan keterampilan.

b) Hasil belajar dinilai dengan pendekatan yang komplementatif pada berbagai unsur hasil belajar guna memberikan umpan balik, sesuai capaian pembelajaran yang harus dikuasai mahasiswa.

c) Nilai menjadi dasar penentuan kelulusan, dengan rentangan angka mutu $0-100$, atau dengan huruf $\mathrm{A}, \mathrm{B}, \mathrm{C}, \mathrm{D}$, dan $\mathrm{E}$.

\section{Metode Penelitian}

Metode penelitian yang digunakan adalah metode survey. Survey riset dikembangkan sebagai bentuk pendekatan positivist pada ilmu-ilmu sosial. Survey menghasilkan informasi yang secara alami bersifat statistik. Survey merupakan bentuk dasar kuantitatif (Groves et al., 2010). Survey dalam penelitian ini digunakan untuk mengetahui sikap dan perilaku mahasiswa dalam proses pembelajaran di masa pandemic covid 19

\section{Jenis Penelitian}

Penelitian ini termasuk jenis penelitian ex post facto, yaitu suatu penelitian dimana variabel bebasnya tersebut telah terjadi, ketika peneliti memulai tindakan pengamatan pada variabel terlikat (Kerlinger, 1973). Peneliti tidak memulai prosesnya dari awal, tetapi langsung mengambil hasil (Sugiyono, 2018).

\section{Waktu dan Tempat Penelitian}

Penelitian ini dilaksanakan pada bulan April 2020 bertempat di Program Studi Pendidikan Fisika Universitas Flores.

\section{Target/Subjek Penelitian}

Target/subjek penelitian adalah seluruh mahasiswa semester II yang sedang mengambil mata kuliah Alat Ukur Fisika yang berjumlah 17 orang.

\section{Prosedur}

Prosedur penelitian meliputi 3 tahapan yaitu; persiapan instrumen pengumpulan data, dan analisis data. Pada tahap persiapan instrument yaitu menyusun instrument berupa kuesioner yang akan digunakan untuk mengumpulkan data aktivitas pembelajaran mahasiswa yang dilaksanakan secara online menggunakan media google classroom. Instrumen terlebih dahulu dilakukan validasi isi dan konstruk untuk melihat kesesuaian pertanyaan/pernyataan dengan indikator penelitian. Validasi dilakukan oleh 2 orang dosen dari Program Studi Pendidikan Fisika yang memiliki keahlian terkait pembelajaran. Pada tahap pelaksanaan pengumpulan data dilakukan pemberian kuesioner kepada subjek penelitian dengan memanfaatkan media google form, karena pengambilan data masih dimasa pandemic covid 19. Selanjutnya, pada tahap akhir adalah melakukan analisis data dan menarik kesimpulan.

\section{Data, Instrumen, dan Teknik Pengumpulan Data}

Data yang dikumpulkan dalam penelitian ini yaitu data primer berupa sikap atau tanggapan mahasiswa berkaitan dengan aktivitas belajar dan data sekunder yaitu prestasi belajar. Instrument atau alat pengumpul data adalah lembar angket (kuesioner). Instrument penelitian terlebih dahulu dilakukan uji validitas isi oleh 2 ahli atau 2 dosen yang kompeten dibidangnya, yang dikenal dengan uji Gregory atau uji Judges (Sudaryono et al., 2013). Hasil validasi untuk kedua validator ahli materi menunjukkan rata-rata skor mencapai $83,22 \%$ dengan kategori valid, sehingga dapat diasumsikan bahwa instrumen layak untuk digunakan (Rawa et al., 2016)

Angket yang diberikan adalah angket tertutup untuk mengukur aktivitas belajar mahasiswa. Skala pengukuran yang digunakan adalah skala Likert yang terdiri dari 5 skala. Dokumentasi digunakan untuk mengambil data terkait prestasi belajar mahasiswa yang berupa nilai akhir semester mata kuliah alat ukur fisika. Penyataan dalam angket terdiri dari penyataan positif dan negatif. Pernyataan yang dibuat 
disusun berdasarkan 6 indikator yaitu; a) perkuliahan online, b) mendownload materi, c) membaca materi, d) berperilaku karena inisiatif sendiri, e) tanggung jawab dan disiplin, serta f) sikap mandiri. Instrumen aktivitas belajar disusun sendiri oleh peneliti dengan mengacu pada dasar teori yang dijabarkan dari definisi operasional variabel, indikator-indikator, kemudian dibuatkan pernyataan atau pertanyaan dalam angket. Teknik pengumpulan data yang digunakan adalah kuesioner atau angket dan dokumentasi

\section{Teknik Analisis Data}

Teknik analisis data yang digunakan adalah analisis deskriptif dengan tahapan yaitu pengumpulan data, penyajian data, reduksi data, analisis data, dan penarikan kesimpulan. Selain itu, analisis yang berkaitan dengan prestasi belajar menggunakan analisis statistik sederhana dengan menghitung mean (rata-rata) dan standar deviasi atau simpangan baku.

\section{Hasil Penelitian dan Pembahasan}

\section{Aktivitas Belajar Mahasiswa}

Aktivitas belajar mahasiswa selama perkuliahan online atau aktivitas belajar mandiri mahasiswa pada masa pandemi covid19 dapat diketahui menggunakan instrumen kuesioner dengan memanfaatkan aplikasi google classroom. Aktivitas tersebut dapat dilihat pada Gambar 1. Kuesioner yang diberikan terdiri dari 13 pernyataan yang dikembangkan dari 6 indikator penelitian yang merupakan bagian indikator aktivitas belajar yang dikemukakan oleh Djamarah (2002), yang mencakup 11 indikator (dalam Zain, 2006).

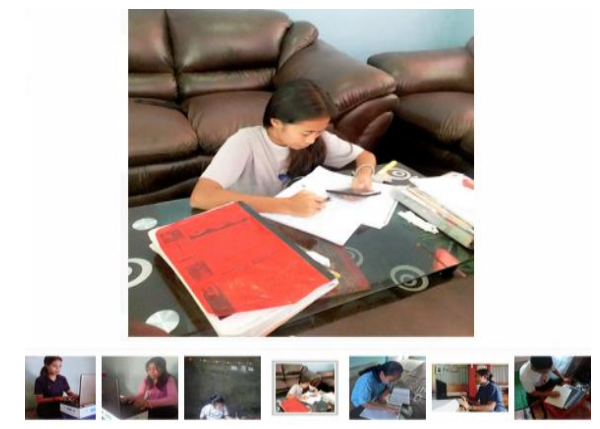

Gambar 1. Aktivitas Belajar Mahasiswa Menggunakan Google Classroom

\section{Prestasi Belajar Mahasiswa}

Prestasi belajar mahasiswa dalam penelitian ini adalah nilai akhir semester yang diambil seluruh proses penilaian pada perkuliahan Alat Ukur Fisika. Hasi nilai ratarata (mean) yang diperoleh dapat dilihat pada Tabel 2; sedangkan hasil isian kuesioner dari 17 responden dapat dilihat pada Tabel 1.

Tabel 1. Persentase Skor Aktivitas Pembelajaran Online

\begin{tabular}{lccc}
\hline \multicolumn{1}{c}{ Indikator } & $\begin{array}{c}\text { Rerata } \\
\text { Skor }\end{array}$ & Kriteria & $\begin{array}{l}\text { Presentasi } \\
(\%)\end{array}$ \\
\hline $\begin{array}{l}\text { Perkuliahan } \\
\text { online }\end{array}$ & 4,2 & Baik & 84 \\
$\begin{array}{l}\text { Mendownload } \\
\text { materi/literatur }\end{array}$ & 4,0 & Baik & 84 \\
$\begin{array}{l}\text { Membaca } \\
\text { materi/literatur } \\
\text { Berperilaku } \\
\text { karena inisiatif }\end{array}$ & 3,6 & Cukup & 72 \\
$\begin{array}{l}\text { sendiri } \\
\begin{array}{l}\text { Tanggung } \\
\text { jawab dan } \\
\text { disiplin }\end{array}\end{array}$ & 4,2 & Baik & 79 \\
Sikap mandiri & 3,5 & Cukup & 85 \\
\hline Hasil & $\mathbf{3 , 9}$ & Baik & 70 \\
\hline Keterangan; skor maksimal setiap indikator yaitu 5
\end{tabular}

Data pada Tabel 1 dan 2 menunjukkan bahwa aktivitas belajar dan prestasi belajar mahasiswa termasuk dalam kategori baik, yang ditunjukkan dari rerata (mean) skor dan nilai. Namun, jika dilihat dari rerata skor pada indikator aktivitas belajar yaitu membaca materi atau literatur dan sikap mandiri, masuk pada kategori cukup.

Tabel 2. Prestasi Belajar Mahasiswa

\begin{tabular}{|c|c|c|c|}
\hline $\begin{array}{c}\text { Peserta } \\
(\mathrm{N})\end{array}$ & Rerata Nilai & $\begin{array}{c}\text { Simpangan } \\
\text { Baku }\end{array}$ & Kategori \\
\hline 17 & 78 & 2,43 & Baik \\
\hline
\end{tabular}

Berdasarkan data yang diperoleh dari hasil penelitian bahwa aktivitas pembelajaran mahasiswa berada pada kategori baik dimasa pandemic covid-19 yang diterapkan dengan system daring menggunakan sistem menejeman pembelajaran google classroom. Pembelajaran secara online bagi mahasiswa di Universitas Flores pada umumnya dan lebih khusus pada program studi Pendidikan Fisika, merupakan cara pembelajaran yang baru pertama diterapkan, walaupun sistem pembelajaran secara daring sudah sejak lama diterapkan di Indonesia. Tingginya antusias mahasiswa 
dalam aktivitas pembelaran online karena sistem pembelajaran secara online lebih memudahkan mahasiswa maupun dosen dalam banyak hal. Salah satu kemudahan adalah mahasiswa dan dosen dapat berinteraksi kapan dan di mana saja namun tetap merasa belajar di dalam kelas. Melalui google classroom membantu students dan teachers untuk mengkomunikan, mengorganisasikan tugas, dan memberikan materi dengan baik (Izenstark \& Leahy, 2015).

Tingginya antusias mahasiswa dalam aktivitas pembelajaran online (e-learning) dipengaruhi oleh reaksi sosial (social influence) yang mengharuskan seseorang bahwa sudah waktunya menguasai dan mengikuti perkembangan teknologi (Lee et al., 2015). Hasil penelitian yang dilakukan oleh Firman \& Rahayu (2020) berkaitan dengan pembelajaran online dimasa pandemic covid 19, juga menyebutkan bahwa mahasiswa sudah lebih siap melakukan pembelajaran online karena didukung dengan fasilitas-fasilitas dasar yang dimiliki seperti gadget, laptop dan juga notebook dan lainnya. Sejalan dengan hasil penelitian yang dilakukan oleh Wayan Suana, bahwa Bleandid Learning sebagai salah satu media pembelajaran yang menggunakan Learning Management System (LMS) yang dikelola secara online mampu meningkatkan prestasi belajar siswa khususnya pada aspek kemampuan berpikir kristis (Suana et al., 2019).

Terdapat dua indikator menunjukkan hasil yang cukup, yaitu membaca materi/literatur dan sikap mandiri. Membaca merupakan suatu kegiatan yang harus diterapkan, atau terus dibiasakan sehingga menimbulkan rasa cinta. Beberapa hasil penelitian menunjukkan bahwa rendahnya minat baca mahasiswa dipengaruhi faktor lingkungan yang kurang mendukung, rasa ingin tahu yang rendah, dan merasa membaca bukan suatu kebutuhan yang sangat penting (Anugra et al., 2013; Farida, 2012; Mudzanatun, 2017).

\section{Simpulan dan Saran}

\section{Simpulan}

Penelitian ini dapat disimpulkan bahwa aktivitas pembelajaran mahasiswa secara umum berada pada kriteri baik dimasa pandemi covid 19 yang diterapkan menggunakan sistem manajemen pembelajaran google classroom.
Berdasarkan masing-masing indikator menunjukkan bahwa; a) perkuliahan online kriteria baik, b) mendownload materi kriteria baik, c) membaca materi kriteria cukup, d) berperilaku karena inisiatif sendiri kriteria baik, e) tanggung jawab dan disiplin kriteria baik, dan f) sikap mandiri kriteria cukup. Pada prestasi belajar mahasiswa termasuk dalam kategori baik.

\section{Saran}

Dari hasil penelitian yang diperoleh maka disarankan bagi penelitian terkait agar menggunakan jumlah subjek/sampel yang lebih representatif serta didukung pula dengan data tambahan dengan teknik wawancara.

\section{Ucapan Terima Kasih}

Terimakasih kepada Rektor Universitas Flores dan juga kepala LPPM Universitas Flores yang telah berkontribusi sehingga pelaksanaan penelitian ini dapat terlaksana.

\section{Daftar Pustaka}

Ananda, R., \& Rafida, T. (2017). Pengantar Evaluasi Program pendidikan. In Medan: Perdana Publishing. https://doi.org/10.1017/CBO97811074153 24.004

Anugra, H., Yusup, P. M., \& Erwina, W. (2013). Faktor-Faktor Dominan yang Mempengaruhi Minat Baca Mahasiswa. Jurnal Kajian Informasi \& Perpustakaan, 1(2), 137-145.

Bagas Panca Pradana, D. (2017). Pengaruh Penerapan Tools Google Classroom pada Model Pembelajaran Project Based Learning terhadap Hasil Belajar Siswa. IT-EDU.

Farida, S. (2012). Faktor-faktor penyebab keengganan membaca di lingkungan mahasiswa: Studi kasus. Seminar Nasional Bahasa.

Firman, F., \& Rahayu, S. (2020). Pembelajaran Online di Tengah Pandemi Covid-19. Indonesian Journal of Educational Science (IJES), 2(2), 81-89. https://doi.org/10.31605/ijes.v2i2.659

Gheytasi, M., Azizifar, A., \& Gowhary, H. (2015). The Effect of Smartphone on the 
Reading Comprehension Proficiency of Iranian EFL Learners. Procedia - Social and Behavioral Sciences. https://doi.org/10.1016/j.sbspro.2015.07.5 10

Groves, R. M., Singer, E., Lepkowski, J. M., Heeringa, S. G., \& Alwin, D. F. (2010). Survey methodology. In A Telescope on Society: Survey Research and Social Science at the University of Michigan and Beyond.

https://doi.org/10.4324/9780429314254-2

Izenstark, A., \& Leahy, K. L. (2015). Google classroom for librarians: features and opportunities. In Library Hi Tech News. https://doi.org/10.1108/LHTN-05-20150039

Kerlinger, F. N. (1973). Foundation of Behavioural Research. American Journal of Educational Research. https://doi.org/10.12691/education-2-1-6

Lee, Y., Lee, J., \& Hwang, Y. (2015). Relating motivation to information and communication technology acceptance: Self-determination theory perspective. Computers in Human Behavior. https://doi.org/10.1016/j.chb.2015.05.021

Mudzanatun, M. (2017). PENYIAPAN PENDIDIK ABAD 21 MELALUI BUDAYA LITERASI. Malih Peddas (Majalah Ilmiah Pendidikan Dasar). https://doi.org/10.26877/malihpeddas.v7i1 .1774

Nirfayanti, N., \& Nurbaeti, N. (2019). Pengaruh Media Pembelajaran Google Classroom Dalam Pembelajaran Analisis Real Terhadap Motivasi Belajar Mahasiswa. Proximal, 2(1), 50-59. https://doi.org/https://doi.org/10.30605/26 15-7667.211

Nurdin, M. (2013). Kiat Menjadi Guru Profesional. AR-RUZZ MEDIA.

Nuriyah, N. (2014). Evaluasi pembelajaran: Sebuah Kajian Teori. Jurnal Edueksos. https://doi.org/10.1165/rcmb.201304110C

Rawa, N., Sutawidjaja, A., \& Sudirman, S. (2016). Pengembangan Perangkat Pembelajaran Berbasis Model Learning Cycle 7E Pada Materi Trigonometri Untuk Meningkatkan Kemampuan Koneksi
Matematis Siswa. Jurnal Pendidikan Teori, Penelitian, Dan Pengembangan. https://doi.org/10.17977/jp.v1i6.6368

Sardiman. (2007). Doc 16. In Interaksi dan Motivasi Belajar Mengajar.

Suana, W., Istiana, P., \& Maharta, N. (2019). PENGARUH PENERAPAN BLENDED LEARNING DALAM MODEL PEMBELAJARAN INKUIRI TERBIMBING PADA MATERI LISTRIK STATIS TERHADAP KEMAMPUAN BERPIKIR KRITIS SISWA Oleh: Jurnal Pendidikan Sains (JPS), 7(2), 129-136.

Sudaryono, Margono, G., \& Rahayu, W . (2013). PENGEMBANGAN INSTRUMEN PENELITIAN PENDIDIKAN. In Journal of Chemical Information and Modeling. https://doi.org/10.1017/CBO97811074153 24.004

Sudjana, N. (2009). Penilaian Hasil Proses Belajar Mengajar. In Sinarbaru.

Sugiyono. (2018). Metode Penelitian Kuantitatif,Kualitatif dan R\&D. In ke-26.

Susilawati, S., \& Sari, I. W. (2019). PEMBELAJARAN FISIKA BERBANTUKAN MEDIA SOSIAL FACEBOOK DAN DAMPAKNYA TERHADAP HASIL BELAJAR FISIKA. Jurnal Pendidikan Fisika. https://doi.org/10.24127/jpf.v7i1.1788

Suyanto, \& Jihad, A. (2013). MENJADI GURU PROFESIONAL: Strategi Meningkatkan Kualifikasi dan Kualitas Guru di Era Global. In Penerbit Erlangga.

Waryanto, N. H. (2006). On-line Learning Sebagai Salah Satu Inovasi Pembelajaran. In Pythagoras.

Zain, S. B. D. dan A. (2006). Strategi Belajar Mengajar. Jakarta: PT Rineka Cipta. Syaiful Bahri Djamarah Dan Aswan Zain. https://doi.org/10.1016/j.bbapap.2013.06.0 07 